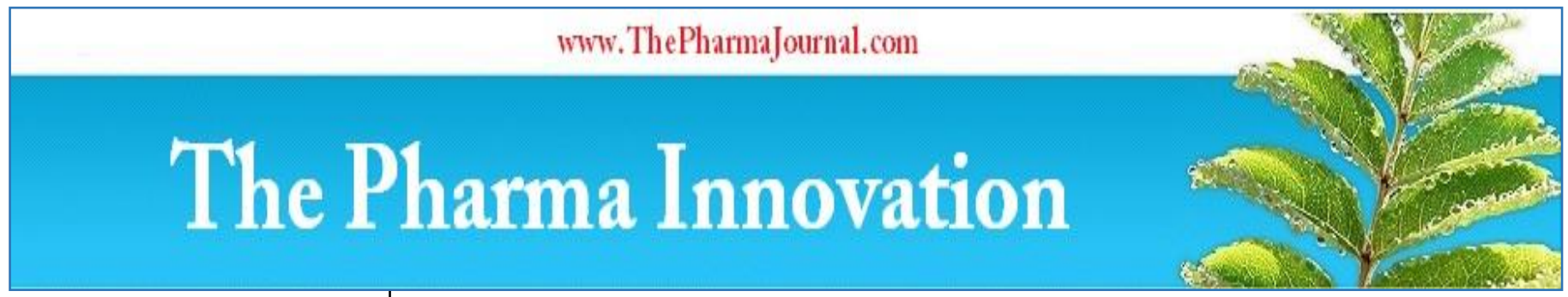

ISSN (E): $2277-7695$

ISSN (P): 2349-8242

NAAS Rating: $\mathbf{5 . 2 3}$

TPI 2021; 10(3): 924-931

(C) 2021 TPI

www.thepharmajournal.com

Received: 07-01-2021

Accepted: 16-02-2021

Sachin Kumar Singh

Department of Soil and Water

Conservation Engineering,

College of Technology, G B Pant

University of Agriculture and

Technology, Pantnagar,

Uttarakhand, India

\section{Akhilesh Kumar}

Department of Soil and Water

Conservation Engineering,

College of Technology, G B Pant

University of Agriculture and

Technology, Pantnagar,

Uttarakhand, India
Corresponding Author: Sachin Kumar Singh

Department of Soil and Water

Conservation Engineering,

College of Technology, G B Pant

University of Agriculture and

Technology, Pantnagar,

Uttarakhand, India

\section{A portable rainfall simulator used for sediment and runoff studies with different land treatments}

\author{
Sachin Kumar Singh and Akhilesh Kumar
}

DOI: $\underline{\text { https://doi.org/10.22271/tpi.2021.v10.i3m.6014 }}$

\section{Abstract}

Sediment outflow and soil erosion is concern in worldwide. This study was conducted in the open field on experimental plots using different soil treatments and its effects on sediment outflow and runoff parameters under varying rainfall intensities and land slope conditions. The study involved large number of field experiments for various combinations of urea applications, surface vegetative conditions, land slopes, periods after urea application and rainfall intensities. To create controlled conditions of rainfall, artificial rainfall was generated by developing a portable rainfall simulation system. Five number of experimental plots of $3 \mathrm{~m}$ length and $1 \mathrm{~m}$ width were constructed and the soil of known properties was filled to create land slopes of $0 \%, 2 \%, 4 \%, 8 \%$ and $12 \%$ in these five number of experimental plots. As per mandate of this study, apart from control (No crop i.e., bare soil), maize crop land and marigold crop land and the conclusion states that maize crop and marigold crop treatment has an important role in the reduction of runoff and sediment outflow.

Keywords: portable rainfall simulator, land slopes, sediment outflow, runoff, rainfall intensity

\section{Introduction}

Rainfall and runoff are major causes of nutrient loss and soil erosion. Water erosion occurs in various forms such as splash, sheet, interrill, rill, gully and stream bank erosion. These processes are governed by a large number of variables pertaining to rainfall, soil type, land topography, crop cover condition and management practices (Wischmier and Smith, 1965) ${ }^{[11]}$. The vegetation above the surface helps in controlling the kinetic energy of falling raindrops and runoff by reducing its flow velocity and the root system below the surface helps in binding of soil material (El Kateb et al., 2013 and Sadeghi et al., 2015) ${ }^{[13,8]}$. In case of erosion by water, rainfall and runoff are the erosive agents, rainfall energy is expended in detaching soil particles and transportability of the sediment depends upon velocity of runoff (Singh et al. 2020) ${ }^{[9]}$. Sediment outflow through runoff, being the important channel among all channels of nitrogen losses, deserves to be given an important emphasis for conducting specific studies in detail (Lal and Mishra, 2015) ${ }^{[7]}$. To conduct scientific studies in detail on relationships between input system parameters and runoff, sediment outflow and nutrient losses and use the available knowledge to apply appropriate control measures to check these losses under various climatic, agronomic and geographic conditions will be of high relevance in present scenario. It is difficult to conduct such studies on varying inputs under actual field conditions, simply because of the reason that in actual conditions, it may not be feasible to obtain requisite number of rainstorms of desired intensity and duration. In such situations, the conduct and replication of experiments under a particular set of combinations of variables are not practically possible as these require huge financial, labour and time resources. Alternatively, as an accepted approach, in this study, an artificial rainfall was generated by developing a rainfall simulation system which is portable and capable of generating artificial rainfall similar to the natural rainfall. Portable rainfall simulation system helped to conduct these studies under actual field conditions with enhanced quality of hydrologic control over various constraints faced with natural rainfall (Clarke and Walsh 2007, Fazlina et al., 2018, and Singh and Kumar, 2020) $[2,4,10]$. The $3.4 \mathrm{~m}$ long and $1.4 \mathrm{~m}$ wide portable rainfall simulation system has been developed by using hypodermic needles fixed at a specified spacing. The rainfall generation unit is placed at $6.0 \mathrm{~m}$ height from the ground on a frame made of mild steel pipes. The entire rainfall simulation system consists of three units as the base, supporting structure, rainfall generation and water supply units. The entire assembly can be dissembled and assembled 
easily and was mounted on wheels to facilitate easy movement from one place to another.

Keeping above facts in consideration, this study was conducted in the open field on experimental plots with maize and marigold crop treatments to know the effects of vegetation cover by crops on sediment outflow and runoff under varying rainfall intensities and land slope conditions (Han et al. 2018) ${ }^{[6]}$. Experiments were conducted for large number of combinations of input variables considering bare land as well as maize and marigold crop land conditions (Ghosh et al., 2015 and Brant et al. 2017) [5, 1]. Runoff samples were collected and analyzed for sediment outflow and runoff from different combinations of rainfall as $3.77 \mathrm{~cm} / \mathrm{h}, 8.82 \mathrm{~cm} / \mathrm{h}$ and $12.73 \mathrm{~cm} / \mathrm{h}$ and land slopes as $0 \%$, $2 \%, 4 \%, 8 \%$ and $12 \%$ with the help of five number of experimental plots of $3 \mathrm{~m} \times 1 \mathrm{~m}$ size and portable rainfall simulator system.

\section{Materials and Methods}

This study was conducted under controlled conditions in the
Department of Soil and Water Conservation Engineering, College of Technology, GBPUA\&T, Pantnagar Uttarakhand using a portable rainfall simulator and experimental plots. The experimental set-up as shown in Fig. 1, basically includes a portable rainfall simulator of $3.4 \mathrm{~m} \times 1.4 \mathrm{~m}$ size for generating simulated rainfall and five experimental plots of 3 $\mathrm{m} \times 1 \mathrm{~m}$ size. The study was conducted under laboratory conditions due to the possibilities of simulating different rainfall intensities with the necessary repetition as well as minute study of the sediment outflow, runoff processes and data collection under varying hydrologic and land treatment conditions.

\section{Portable rainfall simulation system}

To generate artificial rainfall a portable rainfall simulation system was developed to facilitate, conduct and replicate experimentation under controlled conditions. The portable rainfall simulation system was $3.4 \mathrm{~m}$ long and $1.4 \mathrm{~m}$ wide developed by using hypodermic needles fixed at $20 \mathrm{~cm} \mathrm{x}$ $20 \mathrm{~cm}$ spacing.

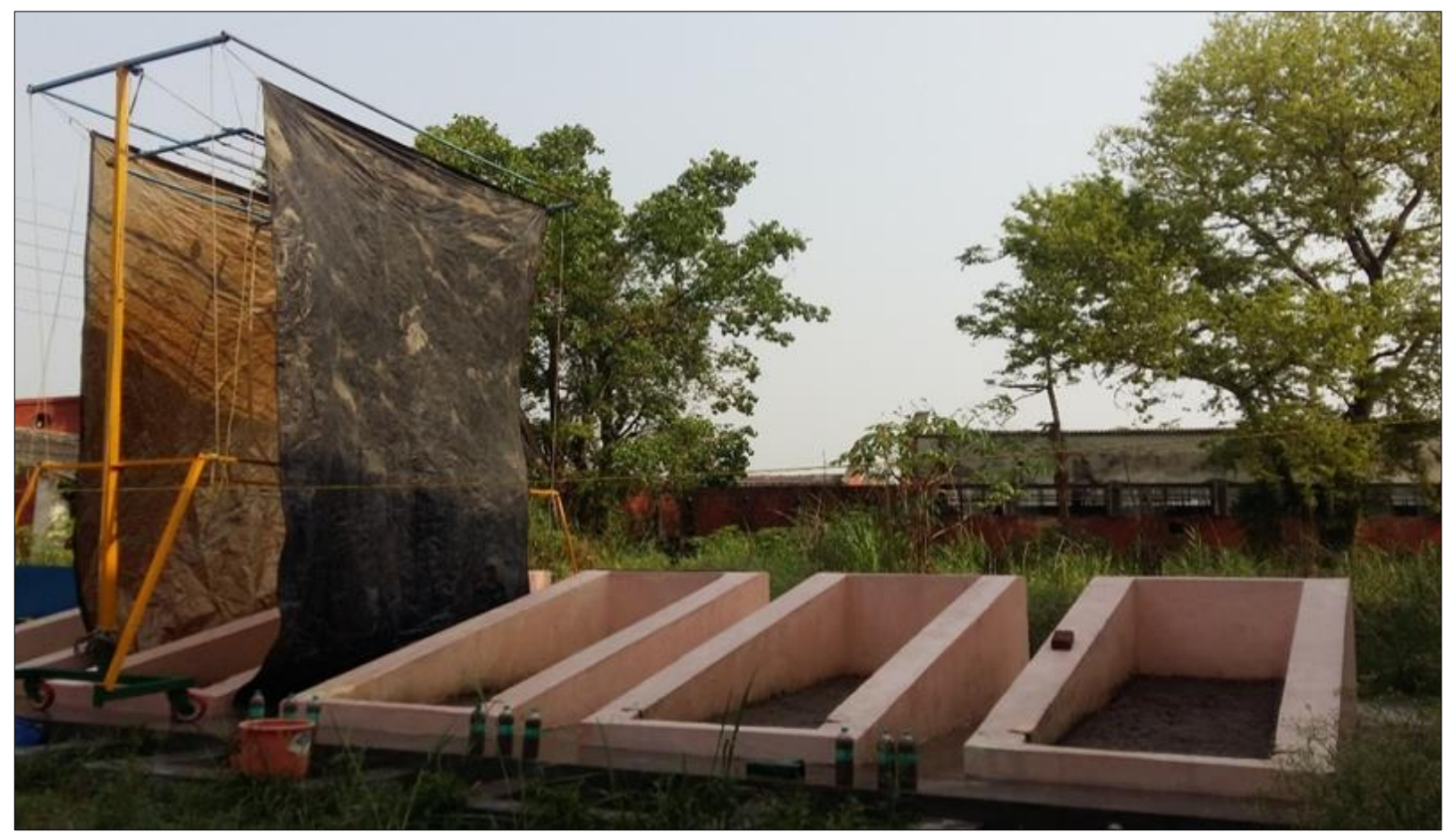

Fig 1: Experimental set-up view

The entire rainfall simulation system consists of four units as the base, supporting structure, rainfall generation, and water supply units. The whole simulation system and accessories were mounted on moving frame supported by wheels for easy movement from one plot to other. The rainfall generation unit was kept at $6.0 \mathrm{~m}$ height from the ground surface and its supporting structure was fabricated by using mild steel square pipes. It was ensured to make it light weight and strong enough to bear the load of the rainfall generation unit. The system can be operated for a water supply pressure of 0.120 $\mathrm{kg} / \mathrm{cm}^{2}$ to $0.800 \mathrm{~kg} / \mathrm{cm}^{2}$ to produce varying intensity of simulated rainfall in the range of $3.77 \mathrm{~cm} / \mathrm{h}$ to $12.73 \mathrm{~cm} / \mathrm{h}$ with raindrop size in the range of $3.05 \mathrm{~mm}$ to $4.76 \mathrm{~mm}$. The uniformity coefficient of the generated rainfall ranged from $82.81 \%$ to $93.52 \%$ in the selected operating pressure range.

\section{Experimental plots}

The experimental plots of $3 \mathrm{~m}$ length and $1 \mathrm{~m}$ width constructed with brick masonry were used for conducting this study. In this study, five land slopes as $1 \%, 2 \%, 4 \% 8 \%$ and $12 \%$ were provided in these 5 number of experimental plots. The efforts were made to create the conditions in the test plot, as similar as possible, to natural site conditions.

\section{Growing of crops}

The study was conducted to observe the nutrient loss and sediment outflow from selected cropping system. As a control condition, nutrient loss and sediment outflow were also observed for no crop system. As per mandate of this study, apart from control (i) No crop i.e., bare soil), (ii) maize crop land and (iii) marigold crop land shown in Fig.2. The maize seeds of Pioneer 1844 variety and Marigold seeds of Pusa Narangi were planted at a depth of 4 to $5 \mathrm{~cm}$ with a row spacing of $50 \mathrm{~cm}$ and plant to plant spacing of $20 \mathrm{~cm}$ of each separate cropping system. 


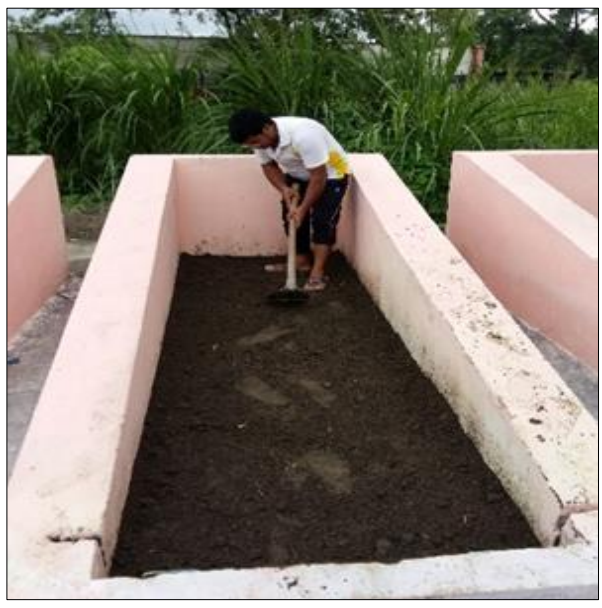

(i) No crop land

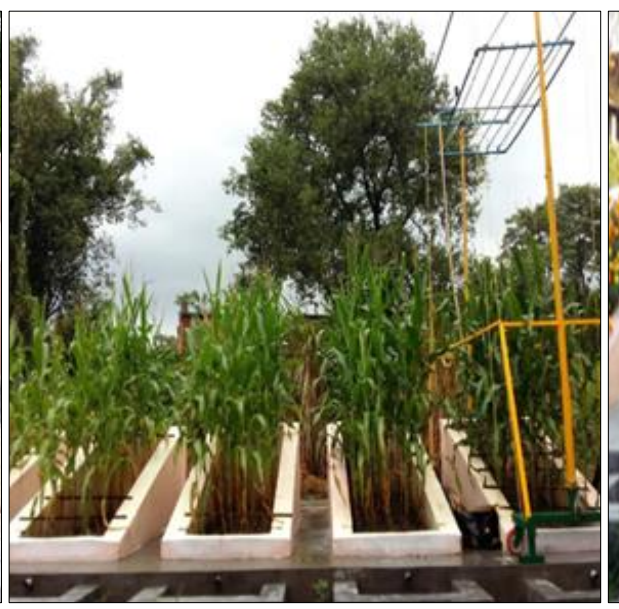

(ii) Maize crop land

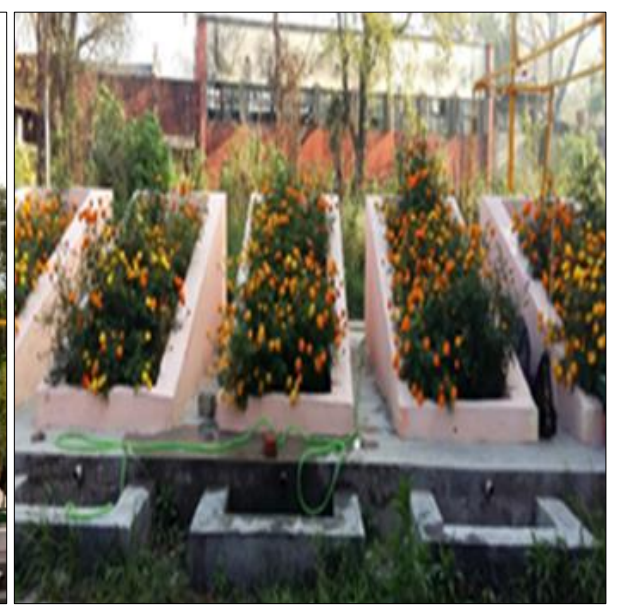

(iii) Marigold crop land

Fig 2: Experimental treatments

\section{Determination of runoff and sediment loss}

The rainfall simulator was operated for a specified duration of 10 minutes and the generated runoff collected in the runoff collection tank and to obtain small representative samples for determining sediment loss. The collected $100 \mathrm{cc}$ runoff samples were put in circular aluminum containers with 75 $\mathrm{mm}$ diameter of $150 \mathrm{ml}$ capacity and of known weight to be put in an electric oven for $24 \mathrm{~h}$, at $105^{\circ} \mathrm{C}$ to determine the sediment concentration.

\section{Result and Discussion}

This experiments conducted in a laboratory to determine sediment loss rate with varying land slopes under selected cropping systems using simulated rainfall. Also, for these conditions' runoff was collected and analysed for sediment loss. Observations were made for bare soil, maize crop and marigold crop at $0 \%, 2 \%, 4 \%, 8 \%$ and $12 \%$ land slopes under simulated rainfall at intensities of $3.77,8.82$ and $12.73 \mathrm{~cm} / \mathrm{h}$. Observed sediment outflow with bare land conditions under $3.77,8.82$ and $12.73 \mathrm{~cm} / \mathrm{h}$ rainfall intensity at selected land slopes.

The sediment outflow rates were observed at selected land slopes under $3.77 \mathrm{~cm} / \mathrm{h}$ rainfall intensity and are tabulated in Table 4.1. The minimum and maximum sediment outflow rate were found as $2240 \mathrm{mg} / \mathrm{m}^{2} / \mathrm{min}$ and $9817 \mathrm{mg} / \mathrm{m}^{2} / \mathrm{min}$ as land slope varied from $0 \%$ to $12 \%$.

Table 4.1: Observed sediment outflow and runoff with bare soil conditions at different land slopes under simulated rainfall

\begin{tabular}{|c|c|c|c|}
\hline Land slope, (\%) & Rainfall intensity, (cm/h) & Volume of runoff, (cc) & Average sediment outflow rate, (mg/m $\mathbf{2} / \mathbf{m i n})$ \\
\hline \multirow{3}{*}{0} & 3.77 & 11200 & 2240 \\
\cline { 2 - 4 } & 8.82 & 24350 & 5544 \\
\cline { 2 - 4 } & 12.73 & 28450 & 6733 \\
\cline { 2 - 4 } & 3.77 & 12400 & 3444 \\
\cline { 2 - 4 } & 8.82 & 28150 & 8382 \\
\hline \multirow{3}{*}{4} & 12.73 & 36900 & 13776 \\
\cline { 2 - 4 } & 3.77 & 11700 & 5215 \\
\cline { 2 - 4 } & 8.82 & 31100 & 17397 \\
\hline \multirow{3}{*}{8} & 12.73 & 41300 & 25422 \\
\cline { 2 - 4 } & 3.77 & 13950 & 8992 \\
\cline { 2 - 4 } & 8.82 & 33800 & 22256 \\
\hline \multirow{3}{*}{12} & 12.73 & 46100 & 33397 \\
\cline { 2 - 4 } & 3.77 & 14800 & 9817 \\
\cline { 2 - 4 } & 8.82 & 36900 & 25830 \\
\hline
\end{tabular}

The sediment outflow rate of $5544 \mathrm{mg} / \mathrm{m}^{2} / \mathrm{min}$ at $0 \%$ land slope, $25830 \mathrm{mg} / \mathrm{m}^{2} / \mathrm{min}$ at $12 \%$ land slope, $8992 \mathrm{mg} / \mathrm{m}^{2} / \mathrm{min}$ under $8.82 \mathrm{~cm} / \mathrm{h}$ rainfall intensity were observed. Similarly, at $12.73 \mathrm{~cm} / \mathrm{h}$ rainfall intensity, the sediment outflow rates varied from $6733 \mathrm{mg} / \mathrm{m}^{2} / \mathrm{min}$ to $35049 \mathrm{mg} / \mathrm{m}^{2} / \mathrm{min}$ as land slope varied from $0 \%$ to $12 \%$. These observations were plotted graphically and are shown in Fig. 4.1. It was in general observed that for a particular rainfall intensity, the sediment outflow rate increased with increasing land slopes with bare soil conditions 


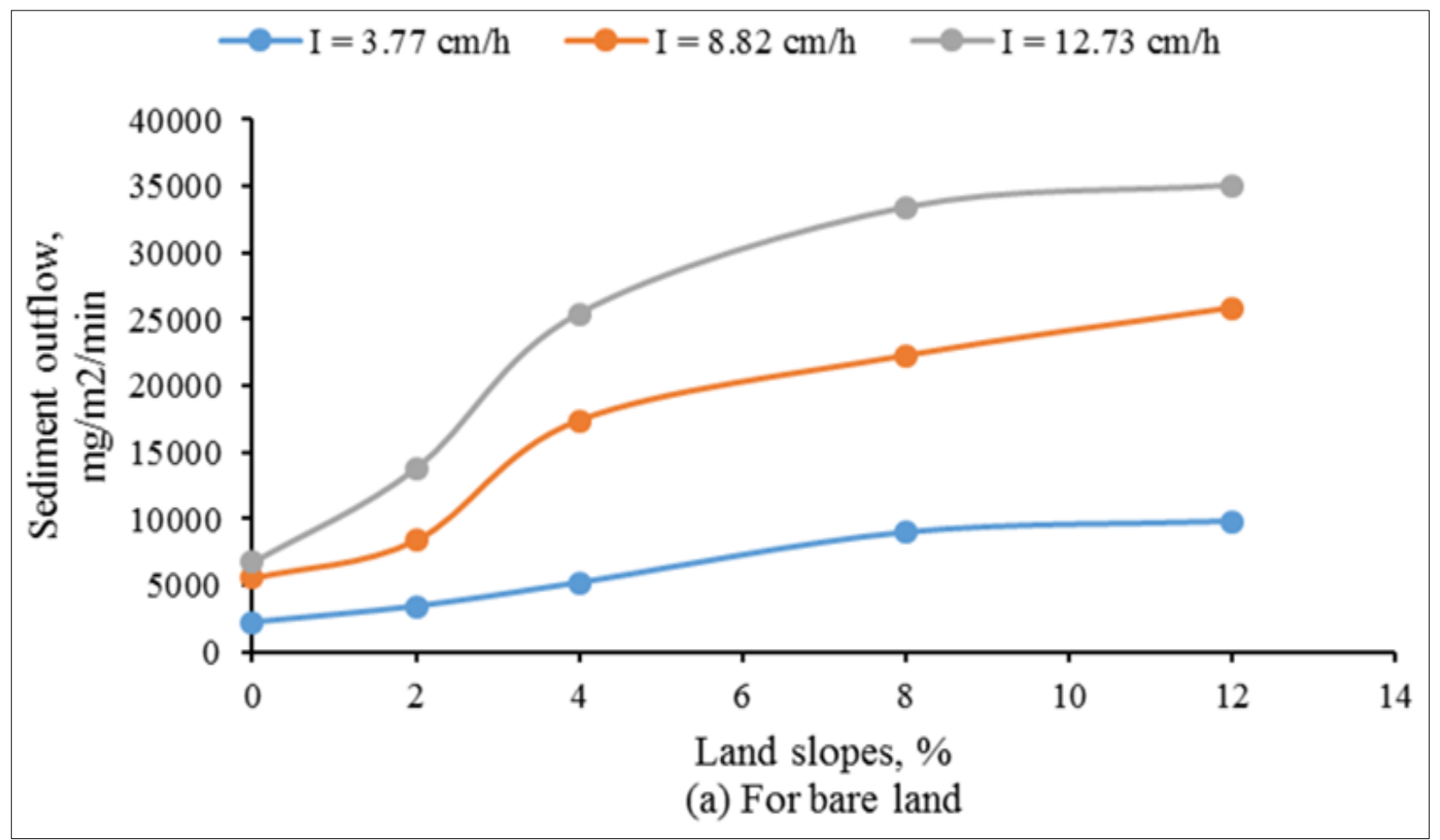

Fig 4.1: Sediment outflow from bare land at selected land slopes under varying rainfall intensity

Observed sediment outflow with maize crop land conditions under $3.77,8.82$ and $12.73 \mathrm{~cm} / \mathrm{h}$ rainfall intensity at selected land slopes.

From Table 4.2, the observations taken for sediment outflow rate clearly indicated that at the specified rainfall intensity, increasing land slope resulted in increased sediment outflow rate from bare land under $12.73 \mathrm{~cm} / \mathrm{h}$ rainfall intensity. The observed data showed that the sediment outflow rates varied from $641 \mathrm{mg} / \mathrm{m}^{2} / \mathrm{min}$ to $4082 \mathrm{mg} / \mathrm{m}^{2} / \mathrm{min}$ under $3.77 \mathrm{~cm} / \mathrm{h}$ rainfall intensity when land slope varied from $0 \%$ to $12 \%$, while it varied from $1281 \mathrm{mg} / \mathrm{m}^{2} / \mathrm{min}$

Table 4.2: Observed sediment outflow and runoff with maize crop conditions at different land slopes under simulated rainfall

\begin{tabular}{|c|c|c|c|}
\hline \multirow{3}{*}{ Land slope, (\%) } & Rainfall intensity, (cm/h) & Volume of runoff, (cc) & Average sediment outflow rate, $\left(\mathbf{m g} / \mathbf{m}^{\mathbf{2}} / \mathbf{m i n}\right)$ \\
\hline \multirow{3}{*}{0} & 3.77 & 6750 & 641 \\
\cline { 2 - 4 } & 8.82 & 12400 & 1281 \\
\cline { 2 - 4 } & 12.73 & 16850 & 2340 \\
\cline { 2 - 4 } & 3.77 & 10700 & 1320 \\
\cline { 2 - 4 } & 8.82 & 15300 & 2023 \\
\hline \multirow{3}{*}{4} & 12.73 & 19300 & 2831 \\
\cline { 2 - 4 } & 3.77 & 9150 & 1739 \\
\cline { 2 - 4 } & 8.82 & 17500 & 3714 \\
\hline \multirow{3}{*}{8} & 12.73 & 22600 & 5198 \\
\cline { 2 - 4 } & 3.77 & 9300 & 2588 \\
\cline { 2 - 4 } & 8.82 & 17300 & 5132 \\
\hline \multirow{3}{*}{12} & 12.73 & 21150 & 7285 \\
\cline { 2 - 4 } & 3.77 & 11200 & 4082 \\
\hline
\end{tabular}

To $7896 \mathrm{mg} / \mathrm{m}^{2} / \mathrm{min}$ when land slope varied from $0 \%$ to $12 \%$ for rainfall intensity $8.83 \mathrm{~cm} / \mathrm{h}$. The sediment outflow rate at $0 \%$ land slope was $2340 \mathrm{mg} / \mathrm{m}^{2} / \mathrm{min}$, at $4 \%$ land slope it was found to be $7285 \mathrm{mg} / \mathrm{m}^{2} / \mathrm{min}$ and at $8 \%$ land slope under $12.73 \mathrm{~cm} / \mathrm{h}$ rainfall intensity. 


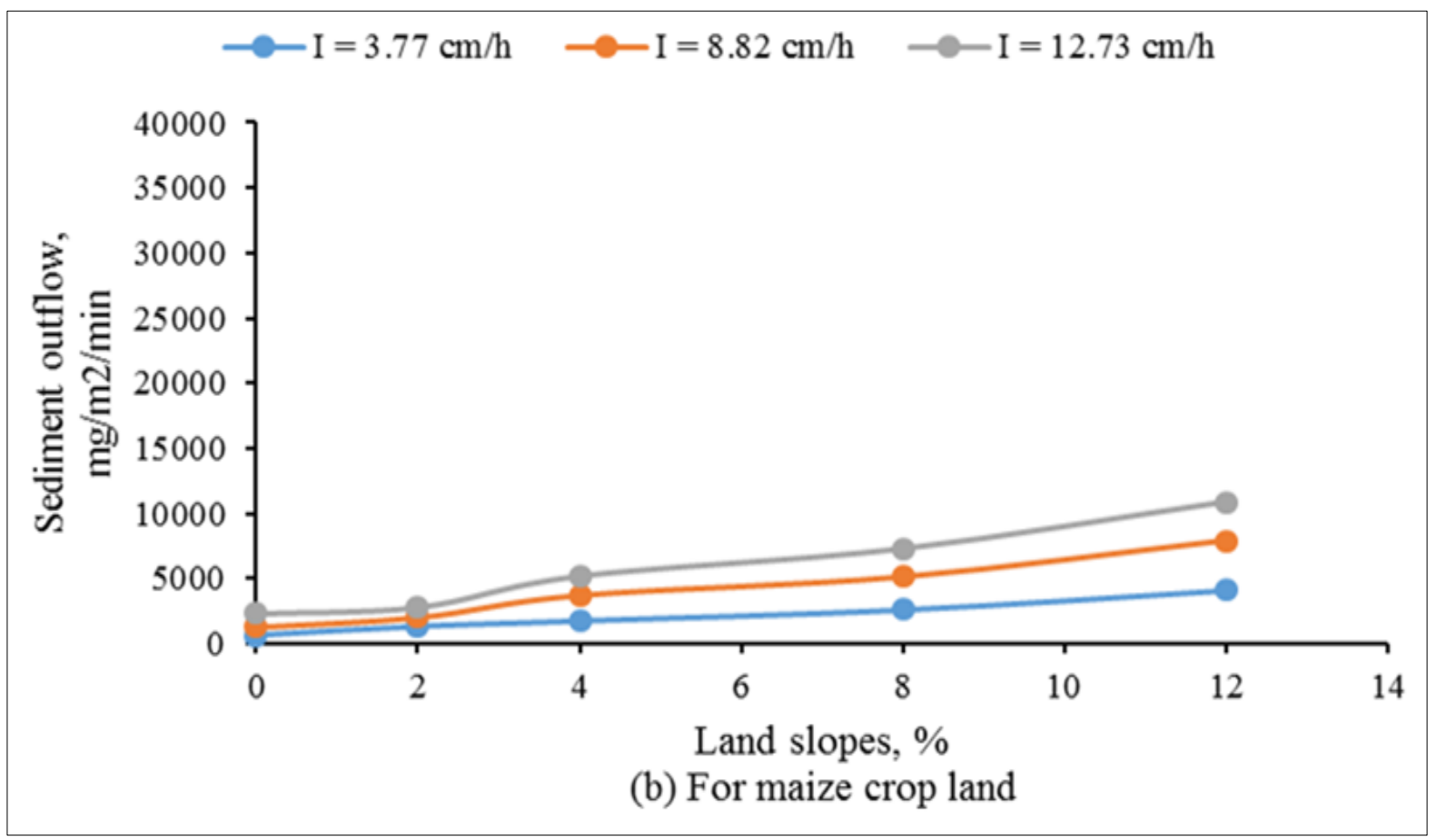

Fig 4.2: Sediment outflow from maize crop land at selected land slopes under varying rainfall intensity

Observed sediment outflow with marigold crop land conditions under $3.77,8.82$ and $12.73 \mathrm{~cm} / \mathrm{h}$ rainfall intensity at selected land slopes.
The sediment outflow rates of $641 \mathrm{mg} / \mathrm{m}^{2} / \mathrm{min}$ at $0 \%$ land slope, $1320 \mathrm{mg} / \mathrm{m}^{2} / \mathrm{min}$ at $2 \%$ land slope, $1739 \mathrm{mg} / \mathrm{m}^{2} / \mathrm{min}$ at $4 \%$ land slope, $2588 \mathrm{mg} / \mathrm{m}^{2} / \mathrm{min}$ at $8 \%$ land slope and 4082

Table 4.3: Observed sediment outflow and runoff with marigold crop conditions at different land slopes under simulated rainfall

\begin{tabular}{|c|c|c|c|}
\hline \multirow{2}{*}{ Land slope, (\%) } & Rainfall intensity, $(\mathbf{c m} / \mathbf{h})$ & Volume of runoff, (cc) & Average sediment outflow rate, $\left(\mathbf{m g} / \mathbf{m}^{\mathbf{2}} / \mathbf{m i n}\right)$ \\
\hline \multirow{3}{*}{0} & 3.77 & 6300 & 526 \\
\cline { 2 - 4 } & 8.82 & 11900 & 1094 \\
\cline { 2 - 4 } & 12.73 & 17950 & 2154 \\
\cline { 2 - 4 } & 3.77 & 9100 & 1107 \\
\cline { 2 - 4 } & 8.82 & 14900 & 1937 \\
\hline \multirow{3}{*}{4} & 12.73 & 18600 & 2542 \\
\cline { 2 - 4 } & 3.77 & 9900 & 1670 \\
\cline { 2 - 4 } & 8.82 & 16850 & 3058 \\
\hline \multirow{3}{*}{8} & 12.73 & 21300 & 4142 \\
\cline { 2 - 4 } & 3.77 & 11200 & 2377 \\
\cline { 2 - 4 } & 8.82 & 17400 & 4485 \\
\hline \multirow{3}{*}{12} & 12.73 & 23900 & 6692 \\
\cline { 2 - 4 } & 3.77 & 10950 & 3833 \\
\cline { 2 - 4 } & 8.82 & 18900 & 7350 \\
\hline
\end{tabular}

$\mathrm{mg} / \mathrm{m}^{2} / \mathrm{min}$ at $12 \%$ land slope, and the minimum and maximum runoff rate were found as $6300 \mathrm{cc}$ to $10950 \mathrm{cc}$ as land slope varied from $0 \%$ to $12 \%$ under $3.77 \mathrm{~cm} / \mathrm{h}$ rainfall intensity as shown in Table 4.3. Similarly, the sediment outflow rates found to $1094 \mathrm{mg} / \mathrm{m}^{2} / \mathrm{min}$ to $7350 \mathrm{mg} / \mathrm{m}^{2} / \mathrm{min}$ under $8.82 \mathrm{~cm} / \mathrm{h}$ rainfall intensity while land slopes varies from $0 \%$ to $12 \%$. From Table 4.3 , the runoff varied from $17950 \mathrm{cc}$ to $25100 \mathrm{cc}$ under $12.73 \mathrm{~cm} / \mathrm{h}$ rainfall intensity while land slopes varied from $0 \%$ to $12 \%$, and similarly, the sediment outflow rate found to be $2154 \mathrm{mg} / \mathrm{m}^{2} / \mathrm{min}$ to 10793 $\mathrm{mg} / \mathrm{m}^{2} / \mathrm{min}$, shown as Fig. 4.3 . 


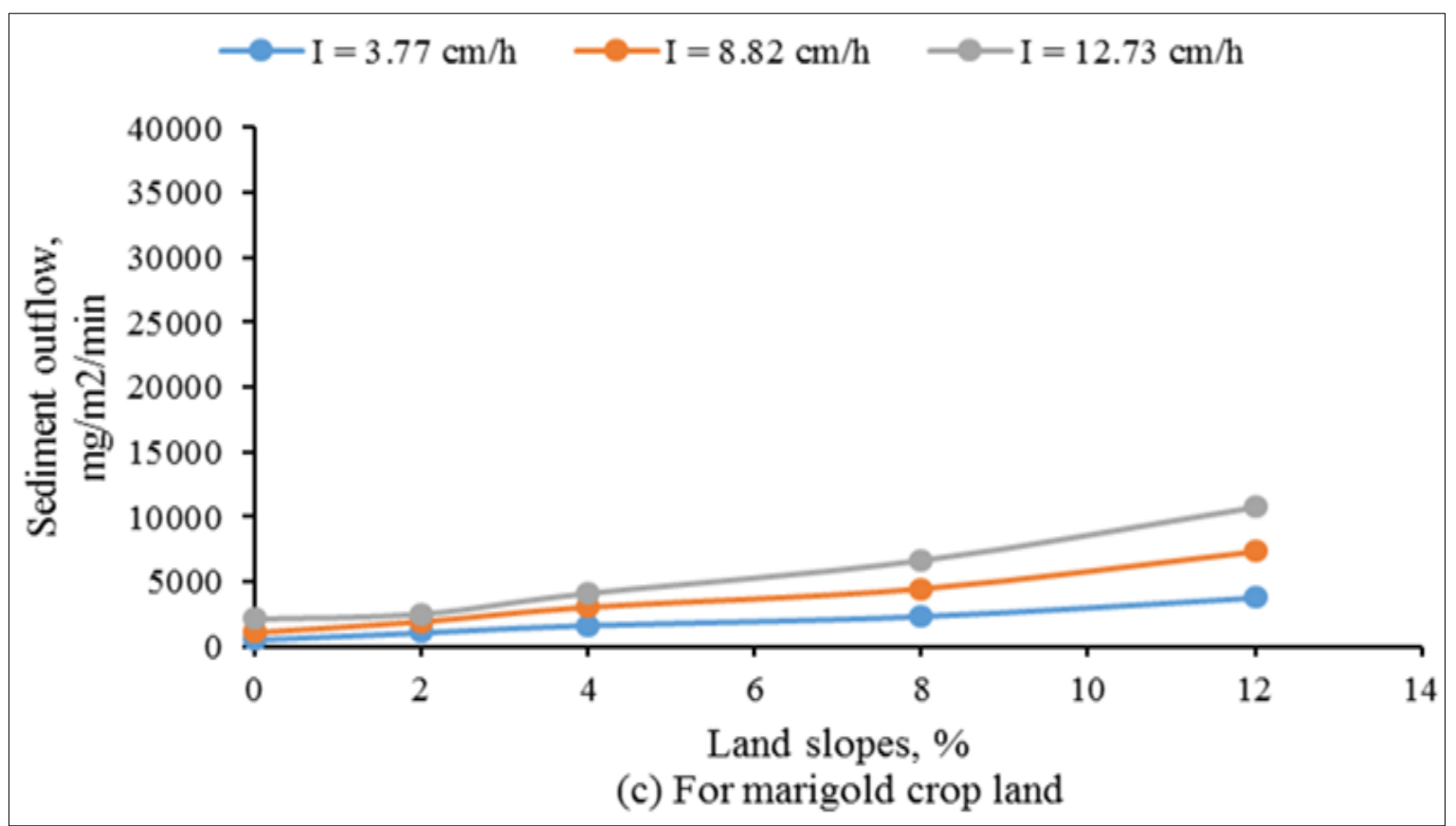

Fig 4.3: Sediment outflow from marigold crop land at selected land slopes under varying rainfall intensity

Comparison of sediment outflow from selected crop treatments at $3.77,8.82$ and $12.73 \mathrm{~cm} / \mathrm{h}$ rainfall intensity on selected land slopes.
The comparative analysis of sediment outflow was performed under similar conditions. These parameters were observed for these applications considering bare land, maize crop land

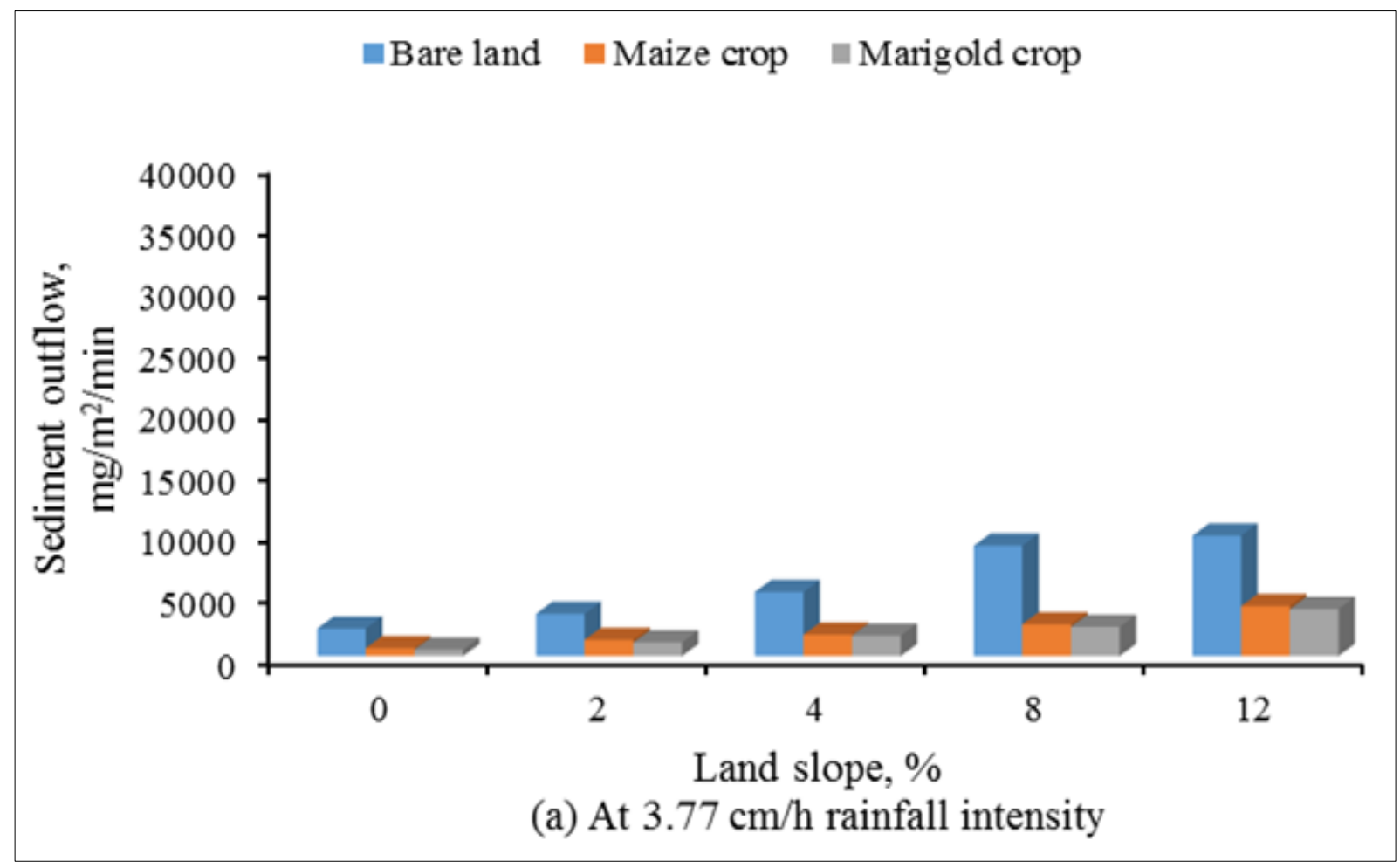

Fig. 4.4: Comparison of sediment outflow from selected crop treatments at $3.77 \mathrm{~cm} / \mathrm{h}$ rainfall intensity on selected land slopes

and marigold crop land at five selected land slopes of $0 \%$, $2 \%, 4 \%, 8 \%$ and $12 \%$ under simulated rainfall conditions with rainfall intensities of $3.77 \mathrm{~cm} / \mathrm{h}, 8.82 \mathrm{~cm} / \mathrm{h}$ and 12.73 $\mathrm{cm} / \mathrm{h}$. The comparative analysis based on the observations recorded in Table 4.1 to Table 4.3 on different treatments is described. The sediment outflow rate at $3.77 \mathrm{~cm} / \mathrm{h}$ rainfall intensity for bare land higher as compare to maize and marigold crop conditions and but In general, because of slow rainfall intensity the volume of runoff create in low quantity. The sediment outflow rate maize and marigold crop treatment not found significant different of both crop treatments as shown in Fig. 4.4. 


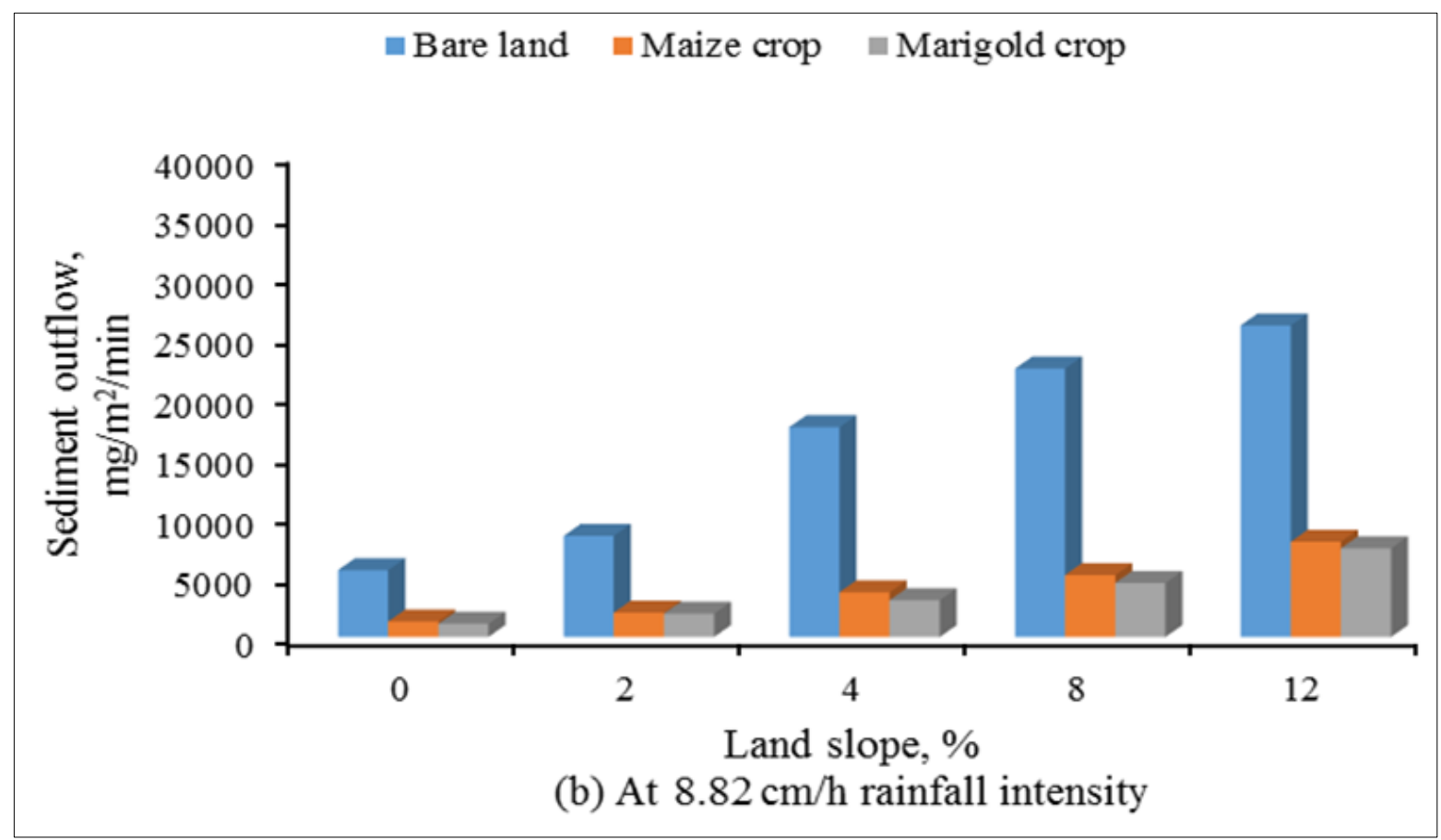

Fig 4.5: Comparison of sediment outflow from selected crop treatments at $8.82 \mathrm{~cm} / \mathrm{h}$ rainfall intensity on selected land slopes

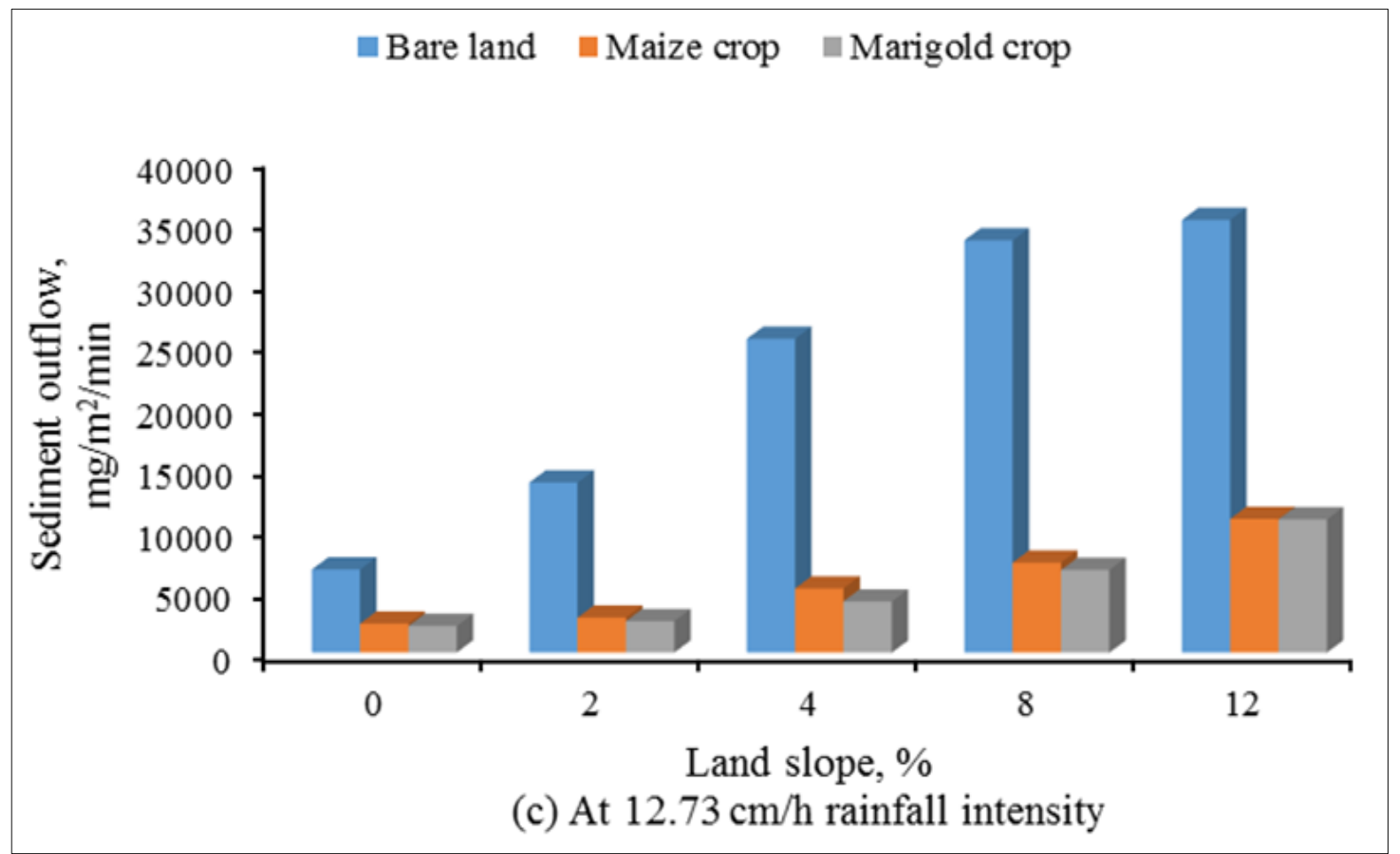

Fig 4.6: Comparison of sediment outflow from selected crop treatments at $12.73 \mathrm{~cm} / \mathrm{h}$ rainfall intensity on selected land slopes

From Fig. 4.5 and 4.6, the sediment outflow rate and runoff from bare land found to be higher as compare to maize crop land and marigold crop land at $8.82 \mathrm{~cm} / \mathrm{h}$ rainfall intensity and 12.73 rainfall intensity on every selected land slopes. Similarly, the sediment outflow rate from maize crop land higher as compare to marigold crop land at similar land slopes and rainfall intensity.

\section{Conclusion}

In this study the sediment outflow and runoff for varying land slopes and simulated rainfall intensities for maize and marigold crop treatments along with bare land treatment were carried out. The study was conducted under simulated rainfall condition with $3.77 \mathrm{~cm} / \mathrm{h}, 8.82 \mathrm{~cm} / \mathrm{h}$ and $12.73 \mathrm{~cm} / \mathrm{h}$ rainfall intensity and $0 \%, 2 \%, 4 \%, 8 \%$ and $12 \%$ of land slopes from bare land, maize crop land and marigold crop land. The effects of various combinations of input variables on sediment outflow and runoff were found to be the for marigold crop treatments better results as compare to maize crop land and maize crop treatments having better results as compare to bare land treatments.

\section{References}

1. Brant V, Kroulík M, Pivec J, Zábranský P, Hakl J, Holec $\mathrm{J}$ et al. Splash erosion in maize crops under conservation management in combination with shallow strip-Tillage 
before Sowing. Soil and Water Research 2017;12(2):106116.

2. Clarke AM, Walsh RPD. A portable rainfall simulator for field assessment of splash and slope wash in remote locations. Earth Surf. Process. Landforms 2007;32:20522069.

3. El Kateb H, Zhang H, Zhang P, Mosandl R. Soil erosion and surface runoff on different vegetation covers and slope gradients: A field experiment in Southern Shaanxi Province, China. Catena. 2013;105:1-10.

4. Fazlina MIS, Azhar ATS, Aziman M. Design, operation and construction of a large rainfall simulator. Civil Engineering Journal 2018;4(8):1851-1857.

5. Ghosh BN, Dogra P, Sharma NK, Bhattacharyya R Mishra PK. Conservation agriculture impact for soil conservation in maize-wheat cropping system in the Indian sub-Himalayas. International Soil and Water Conservation Research 2015;3(2):112-118.

6. Han Y, Feng G, Ouyang Y. Effects of soil and water conservation practices on runoff, sediment and nutrient losses. Water (Switzerland) 2018;10(10):1-13.

7. Lal M, Mishra S. Characterization of surface runoff, soil erosion, nutrient loss and their relationship for agricultural plots in India. Current World Environment 2015;10(2):593-601.

8. Sadeghi SHR, Gholami L, Homaee M, Khaledi Darvishan A. Reducing sediment concentration and soil loss using organic and inorganic amendments at plot scale. Solid Earth 2015;6(2):445-455.

9. Sachin Kumar Singh, Kashyap PS, Daniel Prakash Kushwaha, Sushma Tamta. Runoff and sediment reduction using hay mulch treatment at varying land slope and rainfall intensity under simulated rainfall condition. International Archive of Applied Sciences and Technology 2020;11(3):144-155.

10. Sachin Kumar Singh, Akhilesh Kumar. Development of a portable rainfall simulation system for hydrologic studies under field conditions. International Journal of Current Microbiology and Applied Sciences 2020;9(01):16391648. doi: https://doi.org/10.20546/ijcmas.2020.901.181

11. Wischmier WH, Smith DD. Predicting rainfall erosion losses from crop and east of Rocky Mountains. U.S. Department of Agriculture Agric. Hand Book No 1965;(282):48. 